
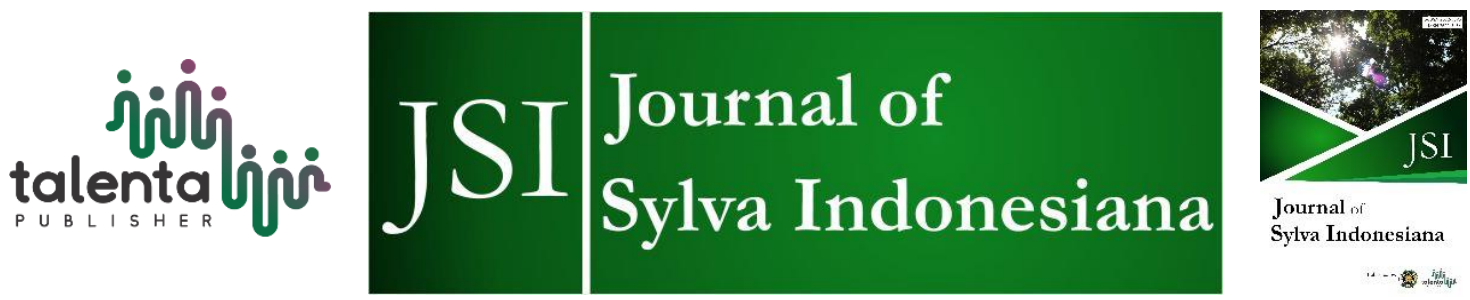

\title{
Conservation of NTFPs Species Through Agroforestry for Community Livelihoods in Sikka, East Nusa Tenggara
}

\author{
Gerson N. Njurumana ${ }^{1}$ and Dona Octavia ${ }^{2 *)}$ \\ ${ }^{I}$ Environment and Forestry Research and Development Institute of Kupang, Indonesia \\ ${ }^{2}$ Forest Research and Development Center, Bogor, Indonesia
}

\begin{abstract}
Conservation and development of non-timber forest product (NTFPs) commodities in East Nusa Tenggara (NTT) are urgently needed. NTFPs are a source of livelihood for the rural communities around the forest areas. NTFPs development around the forest areas is needed as a means to create livelihoods and reduce poverty. The management strategy for forest areas based on integrating conservation and community welfare improvement is needed. The research aims to determine the NTFPs potency in Sikka Regency and the socio-economic conditions of NTFP farmers and to initiate the conservation and development of NTFPs based on the agroforestry approach. The research was conducted through literature review, secondary and primary data collection through surveys, interviews and field observations. The results of the study showed that tamarind (Tamarindus indica L.), candlenut (Aleurites moluccana (L) Willd.), areca nut (Areca cathecu L.), and betel (Piper betle L.) is the major of NTFP commodities in Sikka district. The socio-economic conditions of NTFP farmers on surrounding farmer are not prosperous yet, and highly depend on the sustainability of NTFP production. Community initiatives to conserve and regenerate NTFPs through agroforestry need to be improved, especially in improving the rate of plant growth. Technical assistance to increase community capacity in conservation and development of NTFPs around forest areas and private land is still needed.
\end{abstract}

Keyword: Agroforestry, Communities Livelihoods, NTFPs Species

Received 26 September 2019| Revised 18 October 2019| Accepted 13 November 2019

\section{Introduction}

Forest is a source of life that provides various benefits for humans, such as food, water, energy, health, spiritual, social protection and environmental services [1]-[8]. Forest produces various resources that support community livelihood with a contribution of $17-45 \%$ or an average of $22 \%$ [9]-[15], thus helping to poverty alleviation [16]. Non-timber forest product (NTFPs) is one of the main commodities of forest that plays an important role in the community, especially

*Corresponding author at: Forest Research and Development Center, Bogor, Indonesia

E-mail address: donasyifa@gmail.com 
those in the surrounding forest area. Awareness of the importance of forests, especially as a source of livelihoods originating from NTFPs, has led to a paradigm change in forest management resources from timber-based forest products to non-timber forest products. Timber commodity is still one of the mainstay commodities in the forestry industry, but the carrying capacity of the production forest is only $2.08 \%$ of the per capita requirement [17]. On the other hand, there is a tendency for the progressive use of NTFPs and their ecosystem services, especially in the effort to realize sustainable forest management. By those conditions, [18] stated that improving NTFPs management as an alternative to guarantee sustainable management of forests and their functions, especially on socio-economic and ecological aspects. Based on the biophysical reality of forest resources and the socio-economic conditions of people surrounding forest in East Nusa Tenggara, the optimization of NTFPs management is urgently needed.

The forest resources potency in East Nusa Tenggara reaches 1,784,751 ha (Minister of Forestry Decree Number: SK.3911 / Menhut-II / KUH / 2014). The potency consists of conservation forests covering an area of 516,701 ha (28.95\%), protection forests covering 684,403 ha $(38.35 \%)$ and production forests covering an area of 583,647 ha (32.70\%). Each type of forest management has potential and strategic value, and it will imply to people pressure to utilize it. The condition of land cover is one indicator of forest resource pressure. Non-critical land in East Nusa Tenggara only reaches $6.46 \%$, most of the forest area has an incomplete land cover condition, so that it is classified into critical land, potentially critical, moderate critical and very critical [19]. Pressure on forest areas is closely related to community accessibility and dependence on forest areas. The result of villages surrounding forest area mapping carried out by East Nusa Tenggara Environment and Forestry Province's office showed that there are 2,308 (70.58\%) villages within and around the forest area, generally including underdeveloped villages category. This condition proves the opinion [20] that most of the poor population in developing countries are in rural areas, and depend on the availability of natural resources to meet their needs [8], [21], [22]. This condition can be a reference for the parties to reorient forest areas management, from timber oriented to non-timber oriented.

In line with government programs on poverty alleviation around forest areas, the government adopted a social forestry policy by PP No. 6 of 2007 Jo PP No. 3 of 2008, with several schemes, one of which was P.37/Menhut/2007 concerning Community Forestry (CF). The CF scheme becomes one of the solutions to bridge the community concerns and forest sustainability in Sikka Regency. Through Minister of Forestry Decree No.SK.388/Menhut-II/2010 a CF covering area has been confirmed of 16,755 ha. The decree also followed up with a community forest utilization business permit No: 127/HK/2012 dated May 21, 2012, with an area CF Tuartana's work was 346.88 ha distributed in 227 families. 
The development of NTFPs commodity in CF is one of the conservation strategies to increase forested land cover and poverty alleviation around forest areas. Due to ecological characteristics of forest areas in this area that are generally in semi-arid climates, the development strategic plan is through NTFPs mixed garden or agroforestry approach. Agroforestry is an effort to optimize land use with various types of commodities for various management and utilization in the community. The application of agroforestry can be done through the cultivation of various types of productive plants, such as wood [17] combined with NTFPs commodities that produce food, animal feed, fiber, and medicinal plants. The application of simple agroforestry has been developing for a long time, as indicated by several local agroforestry characteristics in East Nusa Tenggara such as mamar and kaliwu [17]. The characteristics of local agroforestry are characterized by spatial planning, cropping patterns, plant biodiversity and limited land productivity, which has implications for the community.

The development of excellence NTFPs commodities, including tamarind (Tamarindus indica L.), candlenut (Aleurites moluccana (L) Willd.), areca nut (Areca cathecu L.) and betel (Piper betle L.) have contributed significantly to community livelihood and the region. Perda No. 6 of 2017 is legal for NTFPs management in East Nusa Tenggara, especially after the determination of 14 types NTFPs commodities by East Nusa Tenggara Governor Decree No. 404/KEP/HK/2018. Optimizing NTFPs management in East Nusa Tenggara is needed because it can increase regional income. To achieve this program, understanding, and information on NTFPs potency, socio-economic conditions and production capacity of NTFPs farmers and dependence of surrounding communities on forest resources needed to be initiated. This information is needed as a basis for synergizing NTFPs management plans as part of forest management and optimizing the sources of livelihoods of communities around the forest. This research is an effort to reveal about (a) the potential of superior NTFPs in Sikka Regency, (b) the socio-economic conditions of NTFPs farmers, and (c) the capacity of farmers in cultivating NTFPs through agroforestry scheme.

\section{Materials and Method}

\subsection{Time and Location of Research}

The study was conducted from February 2017 to April 2019 in Sikka Regency. The unit of analysis is Tuartana community forest, which is geographically located between coordinates $08^{\circ}$

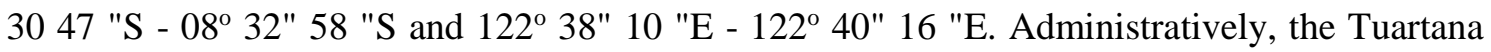
community forest area is included in the Hikong Village area, Talibura District, Sikka Regency, East Nusa Tenggara Province. This location is located at an altitude of between 500 m.asl - 975 m.asl dominated by hilly areas, very steep slopes and composed of cambisol and humic cambisol soil. 


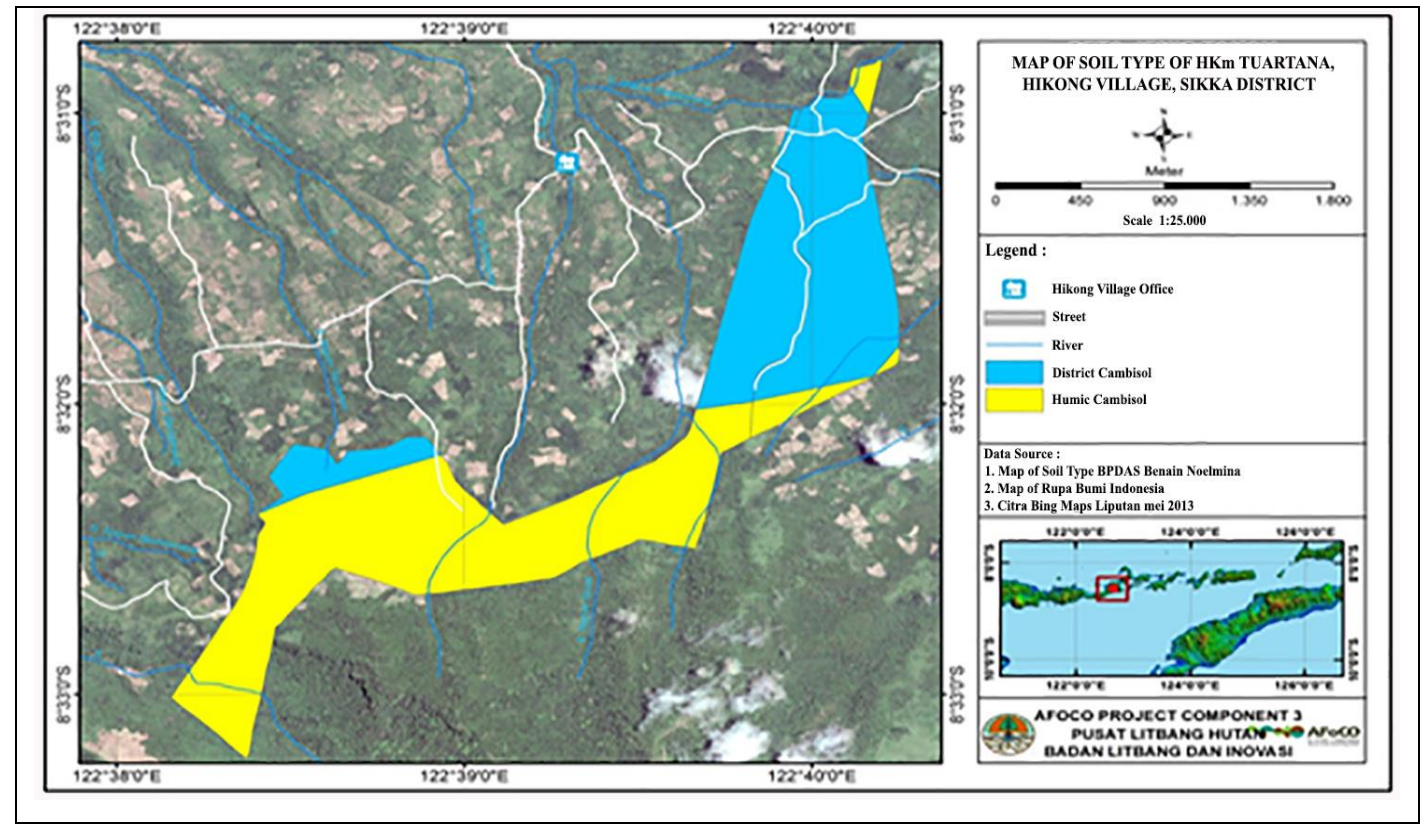

Figure 1 Map of soil type distribution in Tuartana community forest, Hikong Village, Sikka Regency, East Nusa Tenggara.

\subsection{Data Collecting}

Data and information collection is carried out some steps, initially with secondary data collection from agencies related to forestry and natural resource affairs in Sikka District, including the Agriculture and Plantation Office, UPT KPH Sikka Regency, and the Economic Bureau at the Sikka District Secretariat. The secondary data and information including the potency of the production area of each commodity, the number of a family involved in NTFPs cultivation, land productivity, marketing and delivery of NTFP commodities. After obtaining general information on NTFPs potency, it was continued by collecting primary data on the socio-economic conditions of NTFPs farmers who were directly involved in managing the Tuartana community forest. The collected data and information include the area coverable area, dependence on forest resources, accessibility to the CF area and per capita income of CF farmers. Socio-economic data collection was carried out using sampling methods of Tuartana community forest farmers who managed the Wukoh Lewoloroh protected forest area. The sample population of $10 \%$ of 227 families was involved in managing CF, including the representation of family led by women. Purposive random sampling is used in selecting respondents 'criteria, by referring to the criteria for determining respondents [23]-[24], then proceeding randomly to determine respondents' units as sources of information. Surveys and interviews were carried out in parallel by visiting farmer houses, discussing and observing the reality of farmers' lives, including the management of NTFPs species, and field observations on the CF managed land units that are the location of NTFP commodity cultivation. 


\subsection{Data Analysis}

Data and information on NTFPs potency, the socio-economic conditions of NTFPs farmers and the capacity of the community to conserve and develop NTFPs commodities obtained through primary and secondary data collection were analyzed descriptively-qualitatively and descriptive-quantitatively.

\section{Results and Discussion}

\subsection{Potential NTFPs in Sikka Regency}

The management and utilization of NTFPs by the community in Sikka Regency have been going on for a long time, but not all commodities cultivated by the community. The dominant NTFPs potency in Sikka district include cashew nuts (Anarcadium occidentale), cacao (Theobroma cacao), candlenut (Aleurites moluccana (L) Willd), Kapok (Ceiba petandra Gaertn.), cloves (Syzygium aromaticum (L.) Merr \& Perry), areca nut (Areca cathecu L.), pepper (Piper nigrum L.), tamarind (Tamarindus indica L.), jatropha (Jatropha curcas L.), nutmeg (Myristica fragrans Houtt), cotton (Gossypium sp.), betel (Piper betle L.), lontar palm (Borassus flabellifer L.), bamboo (Bamboosa sp.), and other commodities such as honey, arenga sap, lacca, and others.

NTFPs production in Sikka varies greatly, either in this production area, production capacity, productivity and production consistency, including the number of family units involved in NTFPs commodities development. Cacao (Cocoa sp.) and cashew nut (Anarcadium occidentale L.) commodities have the highest production and areas among all NTFPs commodities in Sikka Regency. It indicated by $47.21 \%$ of the total production area used for the cocoa commodity (Theobroma cacao), while $44.60 \%$ is used for cashew commodities (Anarcadium occidentale L.). Both commodities cover $91.82 \%$ of NTFPs production area in Sikka Regency. Other types of commodities found in a small percentage, ranging from 0.164 to $3.031 \%$ of the total production area. The arrangement of NTFPs commodity development areas still relies on cocoa and cashew nut, whether on a monoculture or polyculture scale and independent business on land units owned by the people.

\section{A. $\quad$ Cashew Commodity (Anarcadium occidentale L.)}

The development of cashew in Indonesia has been started since 1975 for critical land rehabilitation [26]. Cashew nuts are international traded food with expensive price per unit weight after vanilla. Indonesia is one of the big cashew producers in the world after India, Vietnam, West Africa, East Africa, and Brazil. But in fact, the cashew international market still dominated by West Africa ( $\pm 25 \%$ of world production), followed by India $( \pm 22 \%)$, Vietnam ( \pm $21 \%)$, Brazil $( \pm 16 \%)$, East Africa $( \pm 9 \%)$ and Indonesia $( \pm 5 \%)$. The cashew production ( \pm $90 \%$ ) commonly produced by small farmers who live in rural areas. East Nusa Tenggara is one of cashew production centers, there are 166,754 ha of cashew production or around $31.89 \%$ of 
the total national production area [25]. For cashew commodities, there are 11,048 ha or 52.05\% of the productive production area, with 32,651 family units involved in their cultivation [19].

Sikka Regency is one of the cashew producers for local and national markets. The total cashew production in this area reaches 21,223 ha or around $12.73 \%$ and $4.06 \%$ of the total area of production at the provincial and national levels. Total production reached $9,937 \mathrm{~kg}$, or equivalent to $22.09 \%$ and $7.22 \%$ of total production at the provincial and national levels [15], [21]. The productivity of cashew in Sikka Regency reaches $899 \mathrm{~kg} / \mathrm{ha}$, higher than the average productivity at the provincial and national levels. The cashew production capacity has increased compared to 2009 which only reached $549,845 \mathrm{~kg} / \mathrm{ha}$ [26]. This condition indicated that cashew management in Sikka District has developed and has a strategic role to fulfill the needs of raw materials at the provincial and national levels.

The cashew cultivation business which is carried out outside or inside the forest area is an indicator of ecological and socio-economic suitability for the community. However, the production of these commodities itself can be dangerous when controlling pest and disease that is not handled properly. Therefore, even from the production aspect and development area indicates that cashew is one of the highest contributors, it is still necessary to be aware of the damage, especially by pests and diseases. If something happens that threatens its production, it will have direct implications for people who are struggling with this commodity.

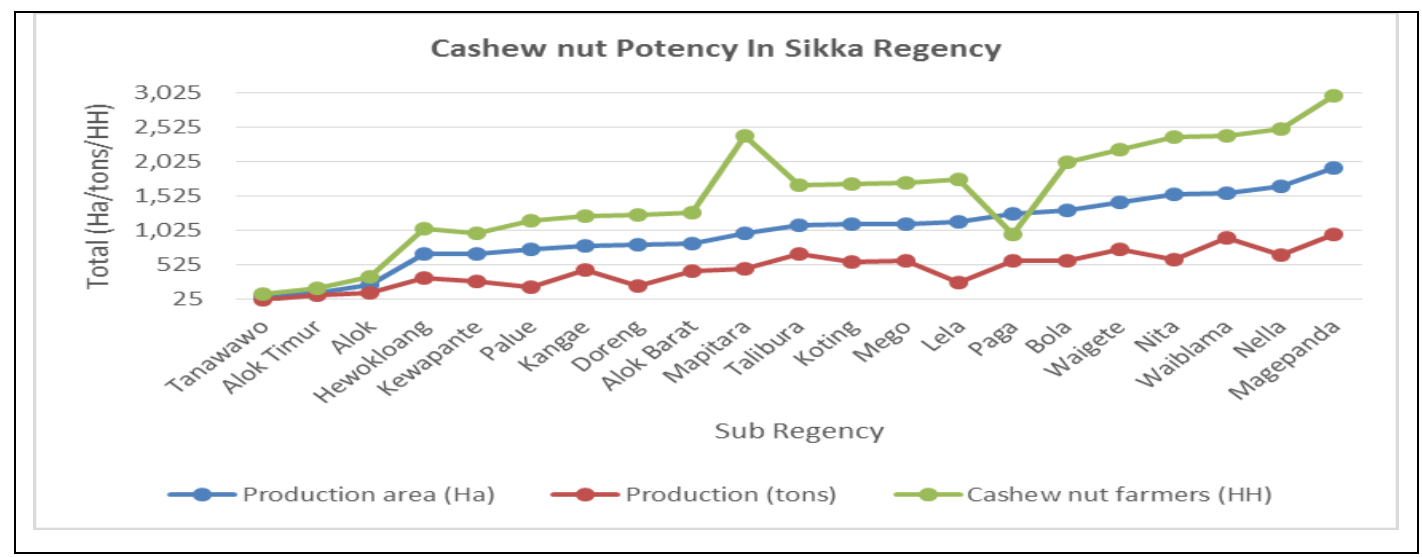

Figure 2 Potential of cashew in Sikka Regency

(Source: Agriculture Office of Sikka Regency, 2018)

Based on commodity zoning, Magepanda, Nella, Waiblama, Nita and Waigete Districts are the main contributors to cashew production in Sikka Regency. The cashew cultivation business is carried out by a majority of the community, as evidenced by 32,651 families in Sikka district or equivalent to $13.30 \%$ and $4.40 \%$ of provincial and national cashew farmers are highly dependent on these commodities. An anomaly occurred in Mapitara District, which is the number of cashew farmers was quite high, while the production area control and production capacity were relatively low. The opposite condition occurs in Paga District. In this area, the 
production is quite high, while farmers number is small. It shows that cashew farmers in Paga District have a better capacity for managing cashew commodities, especially intensification and extensification to increase cashew crop production.

\section{B. $\quad$ Tamarind Commodity (Tamarindus indica L.)}

Tamarind is one of the NTFPs commodities needed in the local, national and even international markets. National tamarind production reaches 13,444.21 tons [27]. Tamarind is one of the commodities that can tolerate drought conditions such as in East Nusa Tenggara and other arid regions in parts of Africa [28]. Tamarind is a very important source of livelihood for local communities in various countries [29], including the provision of ecosystem services for soil fertility and soil biology [30] and health and nutrition [31]. As is the case with local communities in East Nusa Tenggara and Indonesia in general, tamarind is also used for various food and medicine needs, as well as various derivative products.

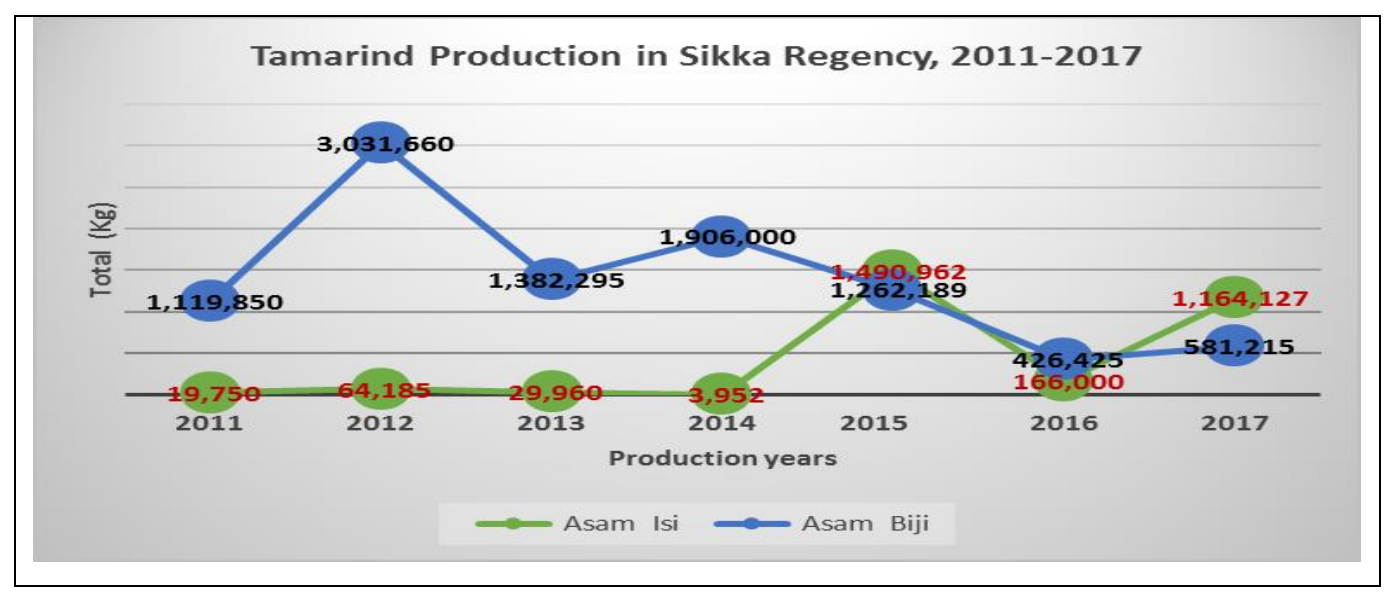

Figure 3 Tamarind production in Sikka Regency (Source: [42])

Tamarind commodity production in Sikka Regency tends to decrease in 2011-2017. The highest production occurred in 2012 as many as 3,031,660 $\mathrm{kg}$ [42], and after that, the production tended to decline. Based on data available at the UPT KPH in Sikka Regency, tamarind commodities are traded nationally. Tamarind trade is generally carried out on an individual so that the flow of trade not well monitored. Tamarind trade to the different island also tends to decrease from 2015 recorded as many as 260,000 kg, transmitted by 20 companies/individuals, then in 2016 decreased to $252,000 \mathrm{~kg}$, transmitted by 6 companies/individuals, then in 2017, it experienced a drastic decrease of $28,800 \mathrm{~kg}$ by 1 company. Based on information from business actors and local governments, tamarind commodities national market is generally sent to Denpasar, Surabaya, Cirebon, Balikpapan and Makassar [34].

\section{C. $\quad$ Candlenut Commodity (Aleurites moluccana (L.) Willd.)}

The candlenut product is very important because many benefits can be obtained from its management. The occurrence of candlenut commodities is expected to accommodate the interests of forest conservation, land and water, and community welfare. Candlenut is one of the 
considerable NTFPs in East Nusa Tenggara Province, and have been used by the community for various needs, one of which is for medicine [32]-[33]. Sikka Regency is one of the candlenut production centers in Indonesia. Based on data and information, the candlenut production area in Sikka Regency reaches 1,008 ha with production reaching 200 tons [34] and production capacity $503 \mathrm{~kg} / \mathrm{ha}$, involving 1,551 families. It means that each family in Sikka has 0.60 ha area for candlenut cultivation, with a production average of $129 \mathrm{~kg} / \mathrm{family} / \mathrm{year}$.

Candlenut is one of the commodities which has a fairly wide production distribution reaching $90.47 \%$ of the subdistrict area in Sikka Regency. Only Alok and west Alok sub-districts have not yet recorded their production, while other sub-districts have produced with a variety of amounts. Palue sub-district has the lowest production, while the Hewokloang sub-district has the highest production. The average candlenut / sub-district production reaches $37,066.86 \mathrm{~kg} /$ year.

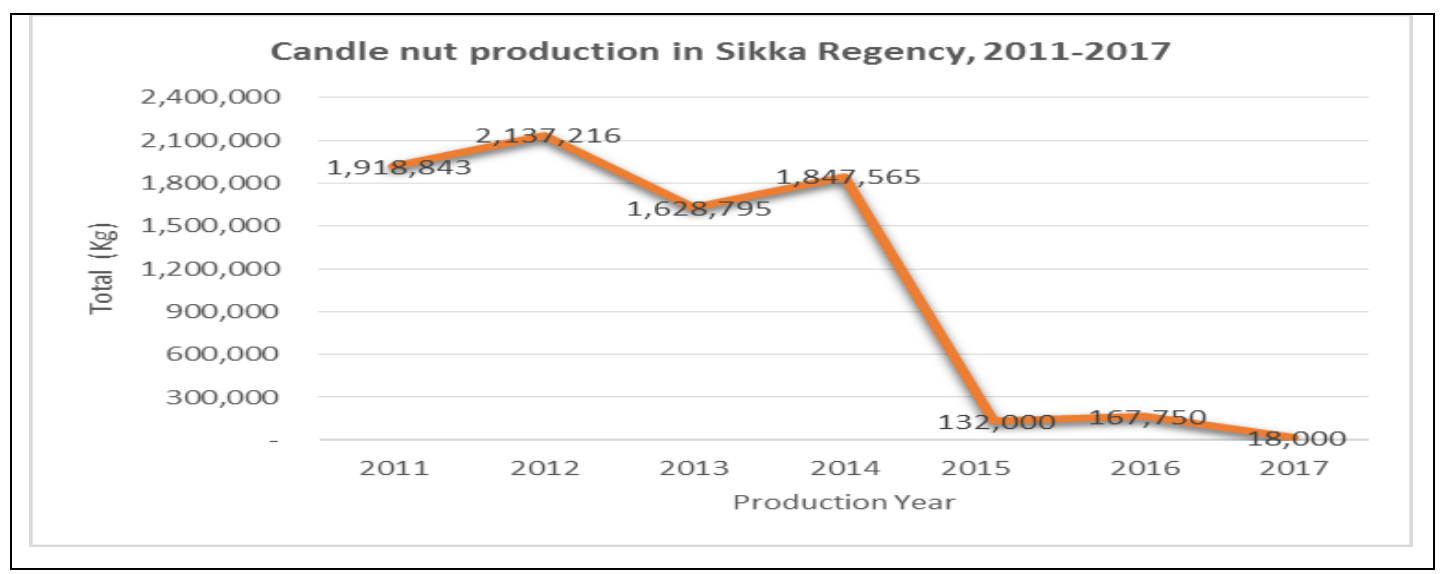

Figure 4 Candlenut production in Sikka Regency (Source: Department of Agriculture, KPH Sikka and SDA Economic Section, BPS and Sikka District Secretariat)

Based on Figure 3, candlenut production was decline since 2015-2017. Even the market to another island process from Sikka regency is higher than production data. In 2015, the market volume reached $132,000 \mathrm{~kg}$, whereas in 2016 increased by $167,750 \mathrm{~kg}$, while in 2017 it experienced a drastic decrease of $18,000 \mathrm{~kg}$ [34]. According to information from farmers, a decrease in production from 2015-2017 caused by strong wind conditions during the flowering season, so many pistils will fall. It causes a very drastic decrease in production, including the data collection process of candlenut production is not carried out optimally. Also, the existing candlenut is generally included in the category of quite old, while low regeneration effort. The sub-districts of Hewokloang, Mego, Doreng, and Nita are the main contributors to candlenuts supply in Sikka Regency. Even so, the ratio between the production area and production capacity is a balance. It might be caused by a very conventional cultivation pattern and postharvesting management. 


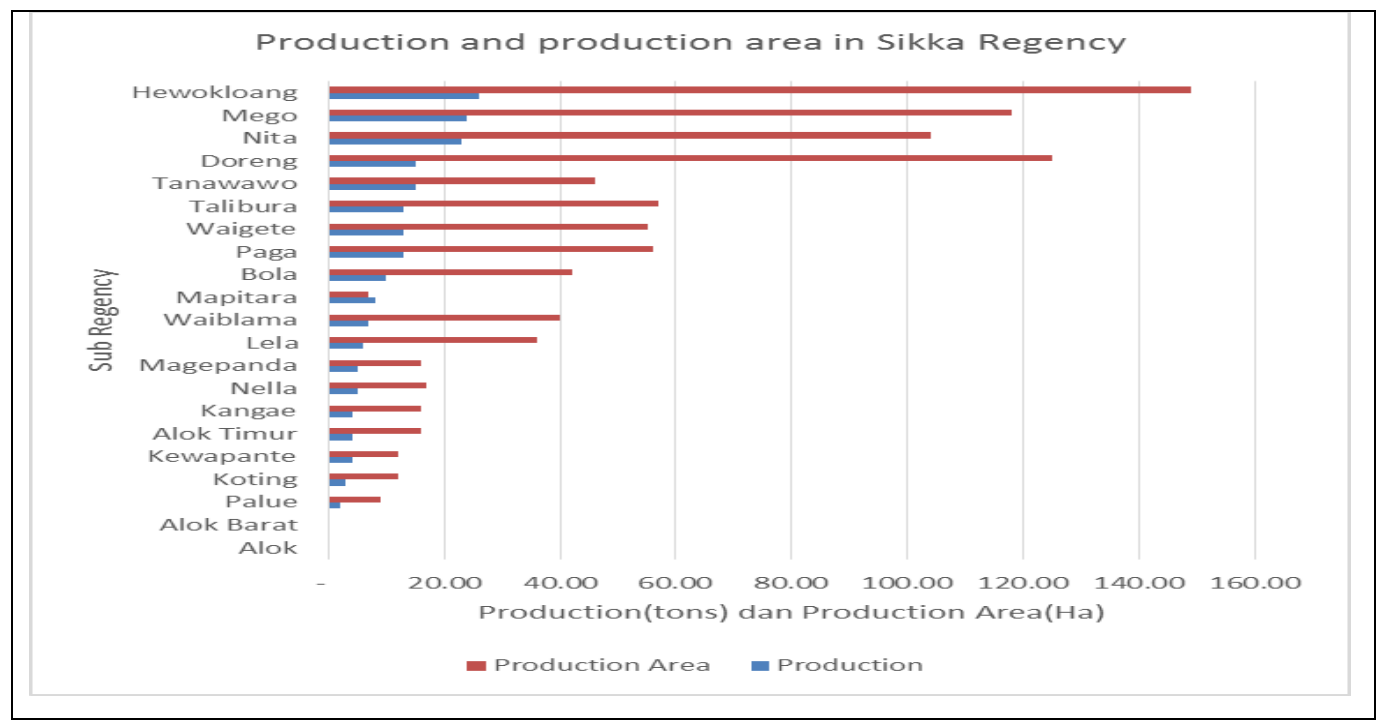

Figure 5 Candlenut production area and production area for each sub-district in Sikka Regency in 2016 (Source: Agriculture Office of Sikka Regency)

D. $\quad$ Areca Nut Commodity (Areca cathecu L.) and Betel Commodity (Piper betle L.) Areca nut (Areca cathecu L.) is one of the NTFPs commodities which is widely used by the international community, especially in Asian countries. Areca nut has been widely cultivated in Asia for a long time since the Ming Dynasty (A.D. 1368-1644). The plant widely cultivated in India, Indonesia, Malaysia, the Philippines and Papua New Guinea [35]-[36]. Areca nut was widely cultivated for fulfilling the demand of high raw materials as many as $10-20 \%$ of the world's population [36]-[39]. A total of $64.5-82.7 \%$ of the Hunan population, China [40], and $35-40 \%$ of East Nusa Tenggara population [41] are areca nut users, mainly for socio-cultural interests. The need for areca nut raw materials at a local level is high. Areca nut production area in Sikka regency is very small as much as 78 ha, with production reaching 17 tons [42] and productivity reaching $321 \mathrm{~kg} / \mathrm{ha} / \mathrm{year}$. The number of families involved in areca nut cultivation is still small, as many as 120 families or around $0.11 \%$ of the family number involved in developing NTFPs [43].

Areca nut and betel are commodities that have very limited distribution in Sikka Regency. Betel commodity is found in $48 \%$ of the subdistrict area in Sikka Regency. Areca nut production ranges from 1000-3000 kg/district/year. Areca nut production is only found in the districts of Lela, Mapitara, Waigete, Doreng, Palue, East Alok, Bola, Paga, Talibura, Tanawawo, and Waiblama. The average productivity of areca nut plants in Sikka is classified as low, at 0.16 tons/ha, far lower than the East Nusa Tenggara average of 0.48 tons/ha [19]. 


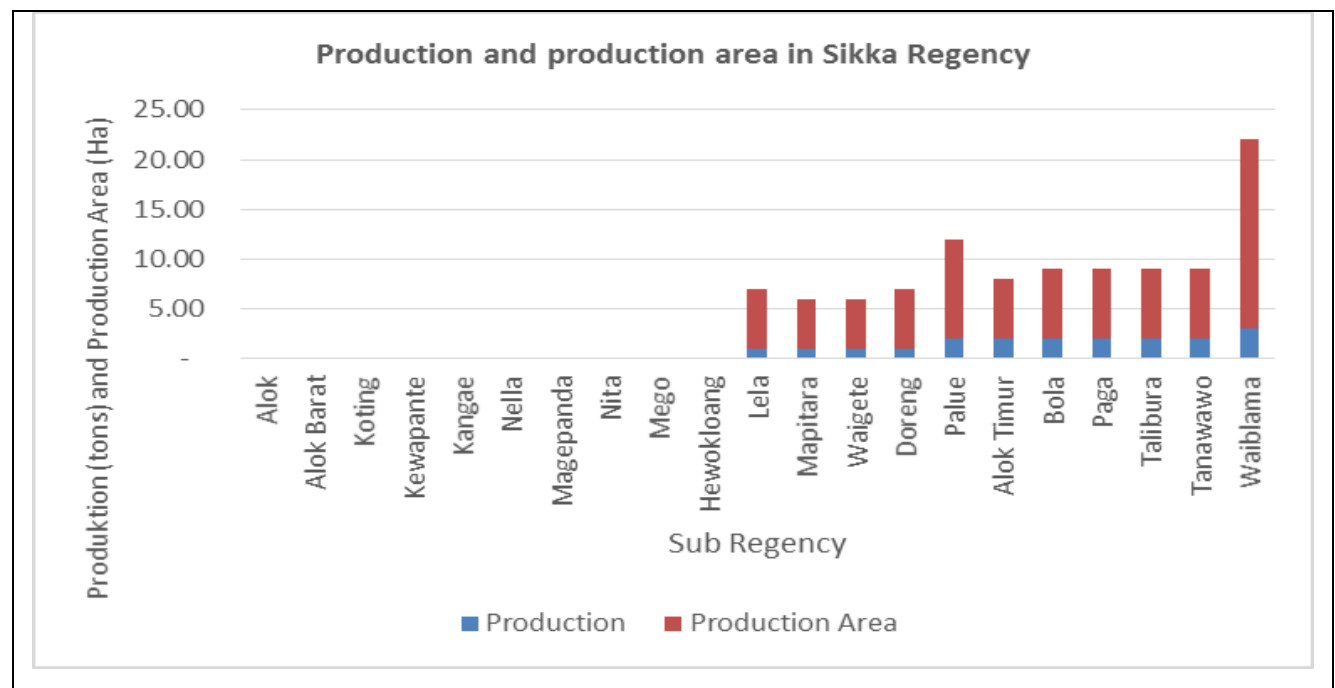

Figure 6 Production and areca nut production area (LAP) for each Sub-district in Sikka Regency in 2016 (Source: Data processed from the Sikka District Agriculture Office)

Based on Figure 5, the highest production area found in Waiblama Sub-district, following by Palue, and other sub-districts. Furthermore, as many as $500 \mathrm{kgs}$ of areca nuts were sent to Oebobo, Kupang by Sea Ship. Specifically for betel commodities, there are no data reported by relevant agencies, both regarding production, area of production, productivity and distribution of growth areas. However, based on information from transportation permit documents to outside the island, there were several times the delivery of betel fruit to Kupang City with a total delivery of $126 \mathrm{~kg}$ using airplane services.

Several types of NTFPs commodities produced in Sikka Regency are sent by distributors to other regions. The main destinations for shipping are Surabaya, Bali, Jakarta, Balikpapan, Cirebon, Kupang and Makassar. Based on data obtained from [42]-[43], the commodity that is mostly shipped out of the region is cashew commodity. The demand for these commodities is quite high, indicated by the number of transmissions that tend to increase.

The NTFPs management requires the integration of parties to balance production and marketing aspects as well as their institutions. This is necessary because there are still overlaps in-licensing of several commodities between the UPT KPH (Forest Management Unit) of the Forestry Service of the Sikka Regency Region with Agriculture and Plantation Service as well as the Economic Section of the Regional Secretariat, Sikka regency.

\subsection{The socio-economic conditions of NTFPs farmers}

The socio-economic condition of NTFPs farmers can be approached from Hikong Village sampling, which is one of the villages in surrounding Wukuh Lewoleroh protected forest area. The hikong village population was 2,196 people and 504 families, 95\% are dryland farmers, forest product collectors and livestock farmers, higher than the Sikka Regency average of $65 \%$ [42]. The large population is not followed by the availability of sufficient land, indicated by 
farming areas ranging from 0.025 to 0.05 ha /capita. Limited expertise and land assets have implications for land productivity and community poverty. Poverty conditions are indicated as many as 2,186 people (99\%), including the underprivileged group, and as many as 305 family units (60\%) are recipients of poor rice (Raskin) assistance from the government [43]. Based on gender, women have a higher poverty vulnerability reaching 1,272 people or $(58 \%)$ of the total poor population [43].

The community limitations and poverty of Hikong Village resident is a general description of the reality surrounding forest poverty. The CF program that has been launched by the government has not had a significant impact on changes in people's welfare. It indicated by 213 families (42\%) in Hikong Village who participate in Tuartana community forest farmers but their socioeconomic conditions not different from communities that have not involved in the $\mathrm{CF}$ program. CF scheme is expected to increase productivity and added value, but the fact, there is no significant difference in socio-economic conditions between $\mathrm{CF}$ farmers and non-CF farmers. Per capita, income and livelihood are indicators for poverty, in this case, the average income of Tuartana community forest farmers is Rp. 276,950/capita/month, below the East Nusa Tenggara provincial poverty line of Rp. 290,363 [19]. Likewise, the average livelihood of CF farmers was very small, amounting to Rp. 150,550/capita/month, below the average Sikka expenditure/capita of Rp. 634,800/month and East Nusa Tenggara Rp. 583,600/month [19], [41]. Providing access to land through the CF scheme requires continuous assistance, including training and capacity building of NTFPs management for farmers, so that limited NTFPs potency can be managed and utilize efficiently, effectively and competitively, and have a significant impact on improving community welfare.

\subsection{Conservation of NTFPs species}

Conservation and development of NTFPs in Sikka Regency have not been well planned. Some types of commodities have been widely cultivated by the community but without a regeneration effort. It causing a decrease of the production area and will have implications for decreasing the potency, production, and productivity of NTFPs commodities. It can be seen in candlenut populations. Agricultural statistical information [21] shows that the candlenut production area reaches 1,008 ha. The production area for young plants reaches 529 ha (52\%), while productive plants reach 398 ha (39\%) which meet the needs of local and national markets. In addition, the area for unproductive plants reaches 81 ha $(9 \%)$. The unproductive area indicated by its physical damage and the age of plant which is more than 35 years [44]. Similar conditions occur in several other commodities, one of which is cashew. It indicates that intervention in cultivation and development for the sustainability of production.

Conservation and cultivation of NTFPs at degraded forest sites need to be increased to restore forest cover and community livelihoods. For example in the case of the Tuartana community forest which is located in a protected forest area. Land cover in protected forest areas has 
currently changed. Recently, the forest was converted into farmland with an area of $124.30 \mathrm{Ha}$ or $35.8 \%$, while closed canopy only covers $117.52 \mathrm{Ha}$ or $33.9 \%$, and open canopy covers 102.27 $\mathrm{Ha}$ or $29.5 \%$ [44]. It can be concluded that changes from intensive land clearing activities for dryland farming in protected areas, resulting in changes in plant composition. Candlenut has dominated the Tuartana community forest region, spreading over various types of land cover, with the mean of diameter and height reaching $30 \mathrm{~cm}$ and 16 meters, with estimated production reaching 45,064 kg/year [44]. This condition changes vegetation structure and composition.

Dryland farming practices that are lead to plant species simplification in the Tuartana community forest area need to be controlled, one of which is through agroforestry inputs. Simple agroforestry with a combination of several plant species has been implemented by farmers, one of which combines cultivation of candlenut, cashew, fruit crops, and upland rice. Topographical factors, soil and water conservation, have not used as a considered factor. Therefore, inputs for agroforestry must be more complex in terms of plant species, including land management, soil and water conservation. It is necessary because land topography is dominated by rather steep slopes (15-25\%) covering 107.32 ha or $30.9 \%$, steep slopes (25-40\%) covering 132.54 ha or $38.2 \%$ and very steep slopes ( > 40\%) covering an area of 26.89 ha or $7.8 \%$ [44].

Conservation of NTFPs in complex agroforestry pilots is an integral part of the CF Annual Work Plan (RKT) and Business Work Plan (RKU) to restore plant diversity to Tuartana CF. The agreement was realized through a pilot agroforestry complex covering an area of 10 ha, involving 21 family units with an area of 0.25-1 ha. The developed plant species included nutmeg (Myristica fragrans Houtt), cloves (Syzygium aromaticum (L.) Merr \& Perry), jackfruit (Artocarpus heterophyllus Lam.), durian (Durio zibethinus Murr.), ginger (Zingiber officinale var rubrum rhizome), galangal (Alpinia galangal (L) Willd.), mahogany (Swietenia mahagoni (L.) Jacg.), bitter bean (Parkia speciose Hassk.), candlenut (Aleurites moluccana (L) Willd.), cashew nuts (Aleurites moluccana (L.) Willd.) and areca nut (Areca cathecu L.). Planting patterns and plant composition uses a path system, taking into account ecological suitability, especially plant competition and growing space for productivity.

Conservation and cultivation of NTFPs based on agroforestry draw active community participation from the commodity planning stage, the determination of pilot site units, land clearing, planting, plant protection for extreme environmental impact mitigation and evaluation. Socialization program and accommodation to farmers need is one key to increasing participation and responsibility in the management of pilot units, plant maintenance, replanting and fertilizing. 


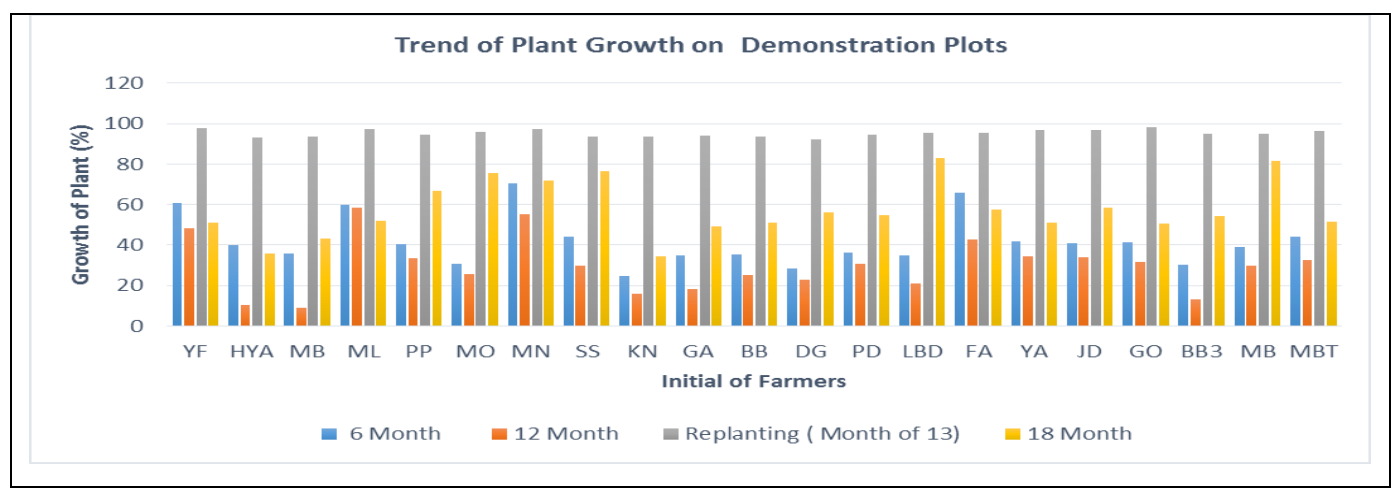

Figure 7 Plants growth performance on each farmers site

Evaluation of community participation in conservation and cultivation of NTFPs in Tuartana CF location is quite high. The success of plant growth in each agroforestry site varies, with average growth at 18 months reaching $61.57 \%$ of the 2,453 plants. It showed good achievement in drought conditions and temperatures reaching $45^{\circ} \mathrm{C}$ in the afternoon in summer. Climate and drought are the main factors that affect plant growth. Water limitations become obstacles to water absorption by plants through roots and have implications for photosynthesis and plant growth. High physical performance and plant diameter experienced slow growth, even though extra efforts through drip irrigation and construction of conventional hoods have been carried out by farmers.

Climate and drought greatly affect plant growth in the Tuartana community forest. The 12 months age of planting later recommended for this condition. The precondition of the growth environment through planting time is also needed, such as shade tree preparation of fastgrowing legumes. The shade tree must be cultivated at least 12 months before planting the main plant so that it has a function as a shade tree and protect the main plant from sunlight and surrounding microclimate.

The potential of NTFPs in Sikka Regency has a strategic value to improve the livelihoods of the community and in the future or forest area ecosystems management and economic empowerment of people surrounding forest. Increased management inputs and attention from the parties for NTFPs commodities development was determining factor for socio-economic changes in the community, which will have a broad impact on improving farmers' incomes, rehabilitation of critical land and conservation NTFPs species. Community participation in the development of NTFPs will increasing forest ecosystem services and which will have a direct impact on people surrounding forest livelihoods [45].

\section{Conclusion}

The NTFPs potency in Sikka Regency is relatively high, but it still requires a regeneration strategy so that the sustainability of production and productivity can be maintained to meet local 
and national market needs. Communities are NTFPs cultivation actors, with their limitation in the capacity, economy, and access to NTFPs-based economic resources terms. It affected the sustainability of NTFPs commodities. Improving farmer capability through various training on aspects of cultivation, harvesting, post-harvest processing, and marketing should be conducted and pay attention to local governments. Drought problems are one of the challenges in the conservation and cultivation of various types of NTFPs commodities in Sikka. Therefore, assistance to optimize NTFPs commodities potency was needed to improving conservation of forest ecosystems and people surrounding forest livelihoods

\section{Acknowledgment}

The authors will be thanks to AFoCo Regional Project Component 3: Facilitating the Participatory Planning of Community-Based Forest Management Using Geographic Information System (GIS) and Remote Sensing (RS) Technologies in Forest Resources Management in the Philippines, Indonesia, and Thailand which have funded research. Our sincere thanks also addressed to Tuartana Community Forest and Hikong Village residents who welcomed, accompanied and participated in the implementation of research and assistance activities.

\section{REFERENCES}

[1] Millenium Ecosystem Assessment, Ecosystem and Human Well-being: Synthesis, Island Press, Washington, DC, 2005.

[2] B. Fisher, S. Polasky, T. Sterner, "Conservation and human welfare: economic analysis of ecosystem services," Environ Res Econ, doi:10.1007/s10640-010-94150. 2010.

[3] S. Jose, "Agroforestry for conserving and enhancing biodiversity," Agroforest Syst, no. 85, pp. 1-8, doi: 10.1007/s10457-012-9517-5. 2012.

[4] S.M. Lee, Y.S. Kim, W. Jaung, S. Latifah, M. Afifi, L.A. Fisher, "Forests, fuelwood and livelihoods-energy transition patterns in eastern Indonesia," Energy Policy, no. 85, pp. 61-70. 2015.

[5] N. Tirivayia, L. Nennena, W. Tesfayea, Q. Ma, "The Benefits of Collective Action: Exploring the Role of Forest Producer Organizations in Social Protection," Forest Policy and Economics, no. 90, pp. 106-114. 2018.

[6] A. Cuni-Sancheza, A.S.K. Ngutec, B. Sonkéd, M.N. Saingee, N.D. Burgessf, J.A. Kleinb, R. Marchanta, "The Importance of Livelihood Strategy and Ethnicity in Forest Ecosystem Services' Perceptions by Local Communities in North-Western Cameroon," Ecosystem Services, vol. 40, no. 101000. 2019.

[7] B.H. Poudyal, T. Maraseni, G. Cockfield, "Impacts of forest management on tree species richness and composition: Assessment of Forest Management Regimes in Tarai Landscape Nepal," Applied Geography, vol. 111, no. 102078. 2019.

[8] E.O. Acheamponga, C.J. Macgregor, S. Sloana, J. Sayer, "Deforestation is driven by agricultural expansion in Ghana's Forest Reserves," Scientific African, vol. 5, no. 00146. 2019.

[9] W. Cavendish, "Poverty, inequality and environmental resources: quantitative analysis of rural households," Centre for the Study of African Economies (CSAE) paper series, vol. 93. 1999.

[10] R. Godoy, H. Overman, J. Demmer, L. Apaza, E. Byron, T. Huanca, W. Leonard, E. Perez, V. Reyes-Garcia, V. Vadez, D. Wilkie, A. Cubas, K. McSweeney, N. Brokaw, "Local benefits of rain forests: comparative evidence from Amerindian societies in Bolivia and Honduras," Ecol. Econ., no. 40, pp. 397-409. 2002. 
[11] M. Fisher, "Household welfare and forest dependences in Southern Malawi," Environment and Development Economics, vol. 9, no. 2, pp. 135-154. 2004.

[12] Getachew, Mamo, E. Sjaastad, P. Vedeld, "Economic dependence on forest resources: a case from Dendi district, Ethiopia," For. Policy Ecol., vol. 9, no. 8, pp. 916-927. 2007.

[13] B. Babulo, B. Muys, F. Nega, E. Tollens, J. Nyssen, J. Deckers et al, "The economic contribution of forest resources use to rural livelihoods in Tigray, Northern Ethiopia," Forest Policy and Economics, vol. 11, no. 2, pp. 123-131. 2009.

[14] P. Vedeld, A. Angelsen, J. BojÖ, E. Sjaastad, G.K. Berg, "Forest environmental incomes and the rural poor," Forest Policy and Economics, vol. 9, no. 7, pp. 869879. 2007.

[15] A. Angelsen, P. Jagger, R. Babigumira, B. Belcher, N.J. Hogarth, S. Bauch, J. Börner, C. SmithHall, S. "Wunder, Environmental income and rural livelihoods: a global comparative analysis," World Dev. 64 (Supplement 1), S12-S28, 2014.

[16] C.M. Shackleton, S.E. Shackleton, E. Buiten, N. Bird, "The importances of dry woodlands and forest in rural livelihoods and poverty alleviation in South Africa," Forest Policy and Economics, vol. 9, no. 5, pp. 558-577. 2007.

[17] G.N. Njurumana, "Management of carpentry wood resources in the Kaliwu agroforest system on Sumba Island, East Nusa Tenggara" In Proceeding of Seminar Nasional Masyarakat Biodiversitas Indonesia, 2015.

[18] J. Chamberlain, A.L. Hammet and P.A. Araman, "Non-Timber Forest Products in Sustainable Forest Management," Available: https:// www.researchgate.net/publication/237632315_nontimber_forest_products_in_sust ainable_forest_management. [Accessed on 20/07/2019].

[19] BPS, Statistics of the East Nusa Tenggara Region, East Nusa Tenggara Statistics (Badan Pusat Statistik) Indonesia, Kupang, 2016.

[20] S. Chen and M. Ravallion, "Absolute poverty measures for the developing world, 1981-2004," Proceedings of the National Academy of Science, vol. 104, no. 43, pp. 1979-2003. 2007.

[21] SPI, Statistik Pertanian Indonesia, Badan Pusat Statistik, 2015.

[22] E.B. Barbier, "Poverty, development, and environment," Environment and Development Economics, vol. 15, no. 6, pp. 635-660. 2010.

[23] G.N. Njurumana, "Village Community and Flora Biodiversity Management in Home Garden System at Central of Sumba Regency," Jurnal Penelitian Kehutanan Wallacea, vol. 5, no. 1, pp. 25-36. 2016.

[24] G.N. Njurumana, Dj. Marsono, Irham, R. Sadono, "Plant Biodiversity Conservation on Kaliwu System at Sumba Island," J. Manusia dan Lingkungan, vol. 21, no.1, pp. 75-82. 2014.

[25] BPS, Statistik Daerah Nusa Tenggara Timur, Badan Pusat Statistik Nusa Tenggara Timur, Kupang, 2017.

[26] D. Listyati and B. Sudjarmoko. "Nilai tambah ekonomi pengolahan Jambu Mete di Indonesia," Buletin RISTRI, vol. 2, no. 2. 2011.

[27] Statistik Kehutanan, Kementerian Lingkungan Hidup dan Kehutanan, Jakarta, 2015

[28] Van der Stege, Christine \& Prehsler, Sarah \& Hartl, Anna \& Vogl, Christian Reinhard, "Tamarind (Tamarindus indica L.) in the traditional West African diet: Not just a famine food," Fruits, no. 66, pp. 171-185. 2011.

[29] T. Ranaivosona, K. Brinkmannb, B. Rakoutha, A. Buerkert, "Distribution, biomass and local importance of tamarind trees in south-western Madagascar," Global Ecology and Conservation, no. 4, pp. 14-25. 2015.

[30] S. Faust, S. Hanisch, A. Buerkert, R.G. Joergensen. "Soil properties under manured Tamarindus indica in the littoral plain of south-western Madagascar," Arid Land Res. Manag., no. 29, pp. 167-179. 2015.

[31] P. Kuru, "Tamarindus indica and its health related effects," Asian Pac J Trop Biomed, vol. 4, no. 9, pp. 676-681. 2014.

[32] S.M. Hoepers, de Souza HGMT., N.L.M. Quintão, J.R. Santin, V.C. Filho, R.M.L. Silva, A.G. Couton, da Silva KABS, "Topical anti-inflammatory activity of semisolid containing standardized Aleurites moluccana L. Willd (Euphorbiaceae) leaves extract," Journal of Ethnopharmacology, no. 173, pp. 251-255. 2015. 
[33] N.L.M. Quintãoa, M.V.D. Pastorb, C.A. de-Souza, G.F. da Silva, L.W. Rochaa, T.E. Bertéa , M.M. de Souzaa, C. Meyre-Silvab,R.M. Lucinda-Silvaa, T.M.B. Bresolina, V.C. Filho, "Aleurites moluccanus and its main active constituent, the flavonoid 2"-Orhamnosylswertisin, in experimental model of rheumatoid arthritis," Journal of Ethnopharmacology, no. 235, pp. 248-254. 2019.

[34] Bidang Ekonomi SDA, Setda Kab. Sikka, Database perizinan pengantarpulauan komoditi HHBK, Sikka, 2018.

[35] Muhammad Asif Asghar, Javed Iqbal, Aftab Ahmed, Mobeen Ahmed Khan and Zuzzer Ali Shamsuddin, "Aflatoxin B1 in betel nuts (Areca catechu L.) imported to Pakistan from different regions of South Asia," Food Additives \& Contaminants: Part B, 2014, vol. 7, no. 3, pp. 176-181. 2013.

[36] W. Peng, Y.J. Liu, N. Wu, T. Sun, X.Y. He, Y.X. Gao, C.J. Wu, "Arecha cathecu L. (Arecaceae) : A review of its traditional uses, botany, phytochemistry, pharmacology and toxicology," Journal of Ethnopharmacology, no. 164, pp. 340356. 2015.

[37] M.S. Amudhan, V.H. Begum, K.B. Hebbar, "A review on phytochemical and pharmacological potential of Areca cathecu L. Seed," International Journal Pharmaceutical Science and Research, no. 3, pp. 4151-4157. 2012.

[38] C.D. Heatubun, J. Dransfield, T. Flynn, S.S. Tjitrosoedirdjo, J.P. Mogea, W. Baker, "A monograph of the betel nut palms (Areca: Arecaceae) of East Malesia," Botanical Journal of the Linnean Society, no. 168, pp. 147-173. 2012.

[39] S. Akhtar, "Areca nut chewing and esophageal squamous-cell carcinoma risk in Asians: A meta-analysis of case-control studies," Cancer Causes Control, no. 24, pp. 257-265. 2013.

[40] X. Zhang and P.A. Reichart, "A Review of Betel Quid Chewing, Oral Cancer and Precancer in Mainland China," Oral Oncology, no. 43, pp. 424-430. 2007.

[41] G.N. Njurumana, K.L. Ginoga, D. Octavia, Provision services of Tuartana community forest for communities benefits in Sikka, East Nusa Tenggara, Indonesia: IUFROINAFOR Joint International Conference. 24 - 27 July 2017. Yogyakarta, Indonesia.

[42] BPS, Sikka Dalam Angka, Badan Pusat Statistik Kabupaten Sikka, 2016.

[43] Dinas Pertanian Kabupaten Sikka, Statistik Pertanian Kabupaten Sikka, 2016.

[44] RKU 2017-2027, Rencana Kerja Usaha Hutan Kemasyarakatan Tuartana. Lembaga Hutan Kemasyarakatan Tuartana, Desa Hikong, Kecamatan Talibura, Kabupaten Sikka, Nusa Tenggara Timur, Sikka, 2017.

[45] M.Z. Muttaqin, I. Alviya, M. Lugina, F.A.U. Hamdani, Indartik, "Developing community-based forest ecosystem service management to reduce emissions from deforestation and forest degradation," Forest Policy and Economics, vol. 108, no. 101938. 2019. 